\title{
Modulating effects of humic acids on genotoxicity induced by water disinfectants in Cyprinus carpio
}

\author{
Bianca Gustavino $^{\mathrm{a}, *}$, Annamaria Buschini ${ }^{\mathrm{b}}$, Monica Monfrinotti ${ }^{\mathrm{c}}$, \\ Marco Rizzoni ${ }^{\mathrm{a}}$, Lorenzo Tancioni ${ }^{\mathrm{c}}$, Paola Poli ${ }^{\mathrm{b}}$, Carlo Rossi $^{\mathrm{b}}$ \\ a Dipartimento di Biologia, Università degli Studi di Roma "Tor Vergata”, Via della Ricerca Scientifica, O0133 Rome, Italy \\ b Dipartimento di Genetica Antropologia Evoluzione, Università degli Studi di Parma, Parma, Italy \\ ${ }^{\mathrm{c}}$ Laboratorio di Ecologia Sperimentale e Acquacoltura, Dipartimento di Biologia, \\ Università degli Studi di Roma "Tor Vergata”, Rome, Italy
}

Received 30 March 2005; received in revised form 3 August 2005; accepted 8 August 2005

Available online 3 October 2005

\begin{abstract}
The use of chlorinated disinfectants during drinking-water production has been shown to generate halogenated compounds as a result of interactions of humic acids with chlorine. Such chlorinated by-products have been shown to induce genotoxic effects and consumption of chlorinated drinking-water has been correlated with increased risk for cancer induction in human populations. The aim of this work was to test the potential genotoxic effects on circulating erythrocytes of the fish Cyprinus carpio exposed in vivo to well-waters disinfected with sodium hypochlorite $(\mathrm{NaClO})$, chlorine dioxide $\left(\mathrm{ClO}_{2}\right)$ or peracetic acid $\left(\mathrm{CH}_{3} \mathrm{COO}_{2} \mathrm{H}, \mathrm{PAA}\right)$, in the absence or presence of standard humic acids (HA). The effects were measured by use of the micronucleus (MN) and the single-cell gel electrophoresis (Comet) assays at different sampling times after a 3-day exposure period. The exposure to chlorine disinfectants without the addition of HA produced a clear toxic effect. Significant cytogenetic damage (i.e. MN induction) was detected in fish populations exposed to both $\mathrm{NaClO}$ and $\mathrm{ClO}_{2}$ with humic acids. In the Comet assay, a significant decrease of DNA migration was observed in erythrocytes of specimens after exposure to $\mathrm{NaClO}$-disinfected water without $\mathrm{HA}$. No effects were observed in any other experimental condition.
\end{abstract}

(c) 2005 Elsevier B.V. All rights reserved.

Keywords: Drinking-water disinfectants; Humic acids; Fish erythrocytes; Micronucleus test; Comet assay

\section{Introduction}

Disinfection of surface waters for drinking-water production is widely conducted with chlorination, which is known to generate toxic by-products as a result of reac-

\footnotetext{
* Corresponding author. Tel.: +3906 72594812 ; fax: +39062023500

E-mail address: gustavino@bio.uniroma2.it (B. Gustavino).
}

tions of chlorine with naturally occurring humic acids [1-3]. These organic halogenated compounds induce genotoxic/mutagenic effects [4-8]. Humic acids (HA) constitute the major portion of organic material present in surface waters, deriving from living or decaying vegetation or microbial decomposition processes [5]; they are usually quantified in terms of total organic carbon (TOC).

A correlation between consumption of chlorinated drinking-water and an increased risk for cancer has been 
shown from epidemiological studies in human populations [9-12]. Such a correlation has also been confirmed by long-term carcinogenicity studies in rats [13]. Thus, the concern for effects on human health from drinkingwater contaminated with genotoxic compounds is the reason for intensive studies, where the widest spectrum of biological systems and exposure conditions are needed. Indeed, results obtained from different organisms used as bio-indicators have indicated several genotoxic and mutagenic effects of disinfected waters, including drinking-water, after direct exposure of vertebrates [14-18], invertebrates [19,20] and plants [21,22].

Due to the increasing evidence of adverse effects of chlorinated compounds, in some instances - such as in hospitals, laboratories and factories - the use of peracetic acid $\left(\mathrm{CH}_{3} \mathrm{COO}_{2} \mathrm{H}, \mathrm{PAA}\right)$ has been experimentally introduced as an alternative compound for water disinfection [23-25]. PAA was shown to produce, as disinfection byproducts, only carboxylic acids, which exhibit a very low level of genotoxicity [26].

For investigations on the quality of treated waters or polluted aquatic environments with respect to genotoxicity, a useful approach is the in vivo treatment or the in situ exposure of living organisms. The micronucleus (MN) test performed in proliferating cell systems of such exposed organisms is a very common and recommended approach for the detection of genotoxicity of treated waters [14-22]; the use of fish as a suitable bio-indicator has been proposed because of its high sensitivity for the detection of both clastogenic and aneugenic activity (reviewed in [27,28]). The application of the MN assay to circulating erythrocytes of fish has been considered a promising tool for the screening of drinking-water. It has been employed for both in situ exposure to environmental waters [29-33] and laboratory treatments in vivo [33-38]. In particular, this test has been performed in Cyprinus carpio [18,39-41].

Despite the recommended and wide use of this test system, little information is available on fish erythrocyte cell kinetics. Several studies carried out mainly on zebra fish show that the kidney marrow is the organ of definitive hematopoiesis in adult fish, analogous to the mammalian bone marrow, where hematopoietic stem cells are resident: all blood-cell lineages and their precursors are found as a heterogeneous population between the renal tubules and the blood vessels. The kidney marrow displays a cellular complexity comparable to that of the mammalian bone marrow [42]. In some fish, such as trout (Salmo trutta) and perch (Perca fluviatilis), the spleen is an additional or the only site of adult hematopoiesis, respectively [43]. For these cells, a direct estimation on the length of the cell-cycle is not reported in the literature. Direct and indirect estimations on cell-cycle dynamics of different cell types, both from early studies on in vivo proliferating systems [44] and from explanted cell cultures $[45,46]$ indicate an average cell-cycle length of about 3 days. Based on radioisotope labelling experiments, an average lifespan of about 150 days has been estimated for red blood cells in Tinca tinca [47]. According to data from different authors, the estimated time for detection of MN in erythrocytes in circulating blood ranges from the 2nd and 3rd week after a clastogenic treatment $[33,36,41]$, which is compatible with the requirement of at least 100 days for a complete turnover of circulating erythrocytes.

The appearance of MN in circulating fish erythrocytes is the ultimate step in their development: they are generated by segregational errors (due to clastogenic and/or aneugenic events) taking place in the dividing erythropoietic stem cells in the cephalic kidney. The time interval occurring between their initial induction and their detection in the circulating erythrocyte cell population is rather long, depending on the cell-cycle duration, the number of the occurring mitotic events and the time of their detention in the kidney marrow needed for cell differentiation and maturation. Once micronucleated erythrocytes are produced, they persist in the red blood cell population until their removal.

The DNA damage measured by DNA strand breakage represents another sensitive indicator of genotoxicity. In particular, the alkaline single-cell gel electrophoresis assay (Comet assay) has been applied to the aquatic environment, both on vertebrate $[48,49,18]$ and invertebrate organisms (for a review, see [50]). This assay has also been proposed by the German Federal Environmental Agency as a useful test in a graduated testing battery for a reliable detection of genotoxicity of surface waters [51].

In our previous study [18], the genotoxic effects of disinfected lake waters were investigated in different seasons on carps exposed in situ to lake waters treated with three different compounds: two chlorinated chemicals, i.e. sodium hypochlorite and chlorine dioxide, and the newly introduced non-chlorinated compound peracetic acid. The micronucleus test and the Comet assay performed in fish erythrocytes indicated the induction of genotoxic effects by the chlorinated disinfectants. Supported by literature data on the mutagenic effects induced as a result of humic acid chlorination, our positive results were discussed taking into account the formation of genotoxic intermediate compounds, such as adsorbable organic halogens (AOX), which were also found in the treated lake waters [22]. However, some confounding factors had been identified, such as temperature and/or other seasonal/environmental variables. 
Since humic acids are the main organic component of surface fresh waters and because their interaction with chlorinated disinfectants generates genotoxic byproducts [4-8], our attention in the present work is focused on the role of these disinfectants in the induction of genotoxic or mutagenic effects in specific physiological conditions of animals and in a controlled experimental environment.

Genotoxicity assays were performed on circulating erythrocytes of in vivo exposed C. carpio for the analysis of the genotoxic/mutagenic effects of three disinfectants, sodium hypochlorite $(\mathrm{NaClO})$, chlorine dioxide $\left(\mathrm{ClO}_{2}\right)$ and peracetic acid $\left(\mathrm{CH}_{3} \mathrm{COO}_{2} \mathrm{H}, \mathrm{PAA}\right)$, by use of the $\mathrm{MN}$ and Comet assays. Fish were exposed to the disinfectants dissolved in water, with or without humic acids. In view of the possible relevance of the results in relation to drinking-water consumption, we tested the disinfectants at low concentrations: the highest concentration employed ( $0.2 \mathrm{ppm})$ corresponds to the maximum free disinfectant residue adopted in surface water disinfection experiments [18,22]. The humic acids concentration $(0.1 \mathrm{ppm})$ was chosen to obtain a 1:0.32 molar-ratio $\mathrm{C}: \mathrm{Cl}$ for the highest $\mathrm{NaClO}$ concentration and a 1:0.08 molar-ratio for the lowest concentration $(0.05 \mathrm{ppm})$, so as to achieve almost complete reaction of chlorine with organic carbon, according to carcinogenicity/mutagenicity studies $[4,52,53]$.

\section{Material and methods}

\subsection{Well-water analysis}

Measurements of physical-chemical parameters in the aquarium water were carried out before the start of the experiments after filtration (glass fibre filters, Whatman GF/F) determining nitrite (colorimetry, diazotization method), nitrate (colorimetry, cadmium-reduction method), ammonium (colorimetry, indophenol blue) and phosphorus (colorimetry, ascorbic acid method) [54]. Temperature, oxygen concentration and $\mathrm{pH}$ were determined by a Multiline P4 WTW probe. Total organic carbon was also measured (see below).

\subsection{Treatment solutions}

\subsubsection{Disinfectants}

Sodium hypochlorite (NaClO; CAS \#10022-70-5; 15\%, w/v) was from Solvay S.p.A. (Rosignano, LI, Italy). Chlorine dioxide $\left(\mathrm{ClO}_{2}\right.$; CAS \#10049-04-4) from Caffaro (Brescia, Italy) was produced by mixing a hydrochloric acid solution (10\% weight) and a sodium chlorite solution ( $8 \%$ weight) in a weight ratio of 1:1. Peracetic acid $\left(\mathrm{CH}_{3} \mathrm{COO}_{2} \mathrm{H}\right.$; CAS \#79-210 ) was from Promox S.r.l. (Leggiuno, VA, Italy): the peracetic acid solution contains peracetic acid $(15 \%, \mathrm{w} / \mathrm{w})$, hydrogen peroxide $(23 \%, \mathrm{w} / \mathrm{w})$ and acetic acid $(20 \%, \mathrm{w} / \mathrm{w}) . \mathrm{NaClO}$ and
$\mathrm{ClO}_{2}$ were always titrated [55] before use, because of their instability: $\mathrm{NaClO}$ with an iodometric titration and $\mathrm{ClO}_{2}$ with a DPD method (Katalase from Merck, KgaA, Darmastadt, Germany; DPD Total Chlorine Reagent Powder Pillow, HACH Company, CO, USA).

\subsubsection{Solutions}

The disinfectants were used at 0.05 and $0.20 \mathrm{ppm}$ (final concentration), both with and without humic acids.

Before use, all treatment solutions containing the disinfectants alone were freshly prepared $(1000 \times$ concentrated) in $100 \mathrm{ml}$ distilled water. HA solutions $(1000 \times$ concentrated) were prepared by adding up to about $20 \mathrm{mg}$ of humic acids (Fluka, Milano, Italy, CAS \#1415-93-6, ignition residue about $20 \%$ ) in $100 \mathrm{ml}$ distilled water under magnetic stirring, until a TOC value of $100 \mathrm{ppm}$ was reached, as measured by TOC-V CPH (total organic analyzer, SHIMADZU). After disinfectant addition (at 200 and $50 \mathrm{ppm}$ ), the solutions were stored at $4{ }^{\circ} \mathrm{C}$ for at least 3 days before use, in order to let interactions take place. The $\mathrm{C}: \mathrm{Cl}$ molar-ratios of the mixture containing $\mathrm{HA}+\mathrm{NaClO}$ at the highest and lowest chlorine concentrations were about 1:0.32 and 1:0.08, respectively. Each concentrated solution was added to 100-1 aquariums filled with well-water.

Finally, due to a dramatic effect of lethality observed within the first 24-h of exposure to $0.2 \mathrm{ppm}$ of both $\mathrm{NaClO}$ and $\mathrm{ClO}_{2}$ (pure disinfectants) these concentrations were halved: thus, for these two chlorinated compounds, the highest concentration of pure disinfectant employed for fish exposure was $0.1 \mathrm{ppm}$.

\subsection{Fish rearing and experimental conditions}

Young specimens of C. carpio, weight range $30-40 \mathrm{~g}$, obtained by artificial reproduction in the Laboratory of Experimental Ecology and Aquaculture of Tor Vergata, were used in the experiments. Before and after the exposure time $(72 \mathrm{~h})$, fishes were maintained in facilities consisting of 100-1 aquariums fed with filtered well-water (open system) at a temperature of $16-17^{\circ} \mathrm{C}$.

Fish were exposed to the three disinfectants $\mathrm{NaClO}, \mathrm{ClO}_{2}$ and PAA at different final concentrations both with and without humic acids. Two control populations exposed to well-water with or without humic acids were also assessed. Exposure of fish specimens (10 per experimental point) was carried out for $72 \mathrm{~h}$ followed by a recovery time of 30 days. During the treatment time, fish were not fed and aquariums were hermetically closed; a complete renewing of the treatment solutions was carried out every $24 \mathrm{~h}$ to minimize volatilization of the compounds. At the end of the treatment, the usual rearing conditions were given to the fishes until the end of the experiments.

Positive controls were not built into the experimental design, because of the strict regulations for discharging high volumes (1001) of contaminated water. On the other hand, our previous study [18] on carps exposed to lake water with or without $\mathrm{NaClO}, \mathrm{ClO}_{2}$ and PAA disinfection showed the sensitivity of the $\mathrm{MN}$ and Comet assays in monitoring environmental stress and pollutants. Other authors also reported the ability of 
the Comet assay to detect DNA damage induced by environmental contaminants [56,57].

\subsection{Blood sampling}

The blood samplings were carried out by intra-cardiac puncture on anaesthetized fishes $(0.1 \mathrm{~g} / \mathrm{l}$ of MS-222 Finquel, SCUBLA AQUACULTURE, Udine, Italy) with heparinized syringes (sodium heparin, CLARISCO ${ }^{\circledR}$, Schwarz Pharma S.p.A., Milano, Italy). After a 5-min recovery period in wellwater, fish were replaced in their own aquarium.

In order to study the same fish population during the experiment with the two different tests, we adopted the following protocol, which combines with several constraints, such as the ethical limitation in specimen number, the need to prevent animal stress or killing due to successive cardiac punctures, and the need of different sampling times in relation to the peculiar characteristics of each test (the Comet assay detects DNA damage that is induced very early after exposure to genotoxic compounds; $\mathrm{MN}$ are the result of chromosome breaks and/or chromosome malsegregation that require necessarily a passage through mitosis to be revealed).

Blood samples were repeatedly taken from the same fish specimens in each aquarium, for both $\mathrm{MN}$ and Comet assays. The first sampling was conducted immediately before the treatment solutions were added to the water $(t=0)$, for both assays. Then, blood samples for the Comet assay were collected at 3 days [56,57] starting from the introduction of disinfectants into the aquarium, while the samples for the analysis of MN were taken at 15 and 30 days.

\subsection{Comet assay}

The Comet assay was basically performed according to [58]. Cells directly withdrawn from the fish $(20 \mu 1)$ were added to $80 \mu \mathrm{l}$ of $0.65 \%$ low-melting agarose (LMA) in PBS and then transferred onto degreased microscope slides previously dipped in $1 \%$ normal melting agarose for the first layer. The agarose with cells was allowed to solidify for $5 \mathrm{~min}$ at $4{ }^{\circ} \mathrm{C}$ before addition of a final layer of LMA. After agarose solidification, the slides were placed in lysing solution $(2.5 \mathrm{M} \mathrm{NaCl}$, $100 \mathrm{mM} \mathrm{Na}{ }_{2}$ EDTA, $10 \mathrm{mM}$ Tris-HCl, $1 \%$ Triton $\mathrm{X}-100$ and $10 \%$ DMSO, $\mathrm{pH} 10$ ) in a Coplin jar at $4{ }^{\circ} \mathrm{C}$ overnight in the dark.

Alkaline DNA unwinding was carried out in a gel electrophoresis chamber containing a freshly prepared buffer (1 mM Na${ }_{2}$ EDTA, $300 \mathrm{mM} \mathrm{NaOH}$, pH 13) for $20 \mathrm{~min}$ and electrophoresis was performed in the same buffer for $10 \mathrm{~min}$ at $0.78 \mathrm{Vcm}^{-1}$ and $300 \mathrm{~mA}$. DNA unwinding and electrophoresis were performed in an ice-water bath. After the electrophoresis, the slides were washed in neutralization buffer $(0.4 \mathrm{M}$ Tris- $\mathrm{HCl}, \mathrm{pH} 7.5)$. All the steps described above were performed under yellow light to minimize additional UV-induced DNA damage.

After staining with $100 \mu \mathrm{l}$ ethidium bromide $(10 \mu \mathrm{l} / \mathrm{ml})$, observations were made under a fluorescence microscope
(Leitz Dialux 20) equipped with an excitation filter BP $515-560 \mathrm{~nm}$ and a barrier filter LP $580 \mathrm{~nm}$, using an imageanalysis system (Cometa Release ${ }^{\circledR} 2.1$ Sarin, Florence, Italy).

For each sample, coded and evaluated blind, 100 cells ( 50 cells/slide) were analyzed; the number of clouds of DNA fragments - or ghost cells, which represent cellular toxic events such as apoptosis and/or necrosis [59] - was recorded, but not considered for the analysis. The relationship between tailmoment (TM) and comet length was examined by simple linear regression $(R=0.967 ; P<0.001)$. The comet parameter TM was chosen to present the data on genotoxic effects.

Data were analyzed using the statistical and graphical functions of SPSS 11 (SPSS Inc., Chicago, IL, USA). The median tail-moment values were used in a one-way analysis of variance test (GLM, general linear model). If a significant $F$-value of $P<0.05$ was obtained, a Dunnett's multiple comparison versus the control group analysis was conducted.

\subsection{Micronucleus test}

Whole-blood smears were fixed in absolute ethanol for 20 min immediately after sampling; slides were then Feulgen stained (1 h Shiff's reagent after acid hydrolysis for $15 \mathrm{~min}$ at $60^{\circ} \mathrm{C}$ in $1 \mathrm{~N} \mathrm{HCl}$ ) and mounted with dissolved polystyrene in xylene (DPX, Fluka, Milano, Italy). Twenty thousands erythrocytes per fish (10 specimens per experimental point) were analysed blind for the presence of micronuclei, at $1000 \times$ magnification under a light microscope. Only nucleated erythrocytes with intact cellular and nuclear membranes were scored and rounded particles without any connection with main nucleus were accepted as micronuclei (for scoring criteria see also $[33,41,60]$. Statistical evaluation was carried out by nonparametric tests (Mann-Whitney test after a Kruskal-Wallis non-parametric ANOVA). Comparisons were made among fish populations at the first sampling time $(t=0)$. Pairwise comparisons were made for each treatment between samples taken at $t=0$ and samples taken at $t=15$ or 30 days. Finally, regression analyses were carried out on the data obtained for each disinfectant with or without HA, at each sampling time.

\section{Results}

\subsection{Well-water analysis}

Physical-chemical values (mean \pm S.D.) of the water parameters measured in the aquariums before the start of the experiments were as follows: temperature, $16.4 \pm 0.5^{\circ} \mathrm{C} ; \mathrm{pH} 7.4 \pm 0.3 ; \mathrm{O}_{2}$ concentration, $7.6 \pm 0.2 \mathrm{mg} / \mathrm{l} ; \mathrm{O}_{2} \%$ saturation, $80.3 \pm 2.5$; $\mathrm{N}-\mathrm{NO}_{2}<0.02 \mathrm{mg} / \mathrm{l} ; \quad \mathrm{N}-\mathrm{NO}_{3}=0.91 \pm 0.03 \mathrm{mg} / \mathrm{l} ; \quad \mathrm{N}-$ $\mathrm{NH}_{4}<0.2 \mathrm{mg} / \mathrm{l} ; \mathrm{P}_{-} \mathrm{PO}_{4}<0.02 \mathrm{mg} / \mathrm{l}$. The mean TOC value was $9.6 \pm 3.1 \mu \mathrm{g} / \mathrm{l}$. In addition, measurements of heavy metal content (cadmium, copper, mercury, 
zinc), performed for water-quality assessment in the aquaculture plant, showed values (data not reported) far below the limits recommended to protect the health of cold- and warm-water fish in intensive culture [61]. The data altogether indicate a good water quality, which is adequate to minimize the sources of confounding factors.

\subsection{Biological assays}

A strong toxic effect was evident for pure chlorinated disinfectants (Tables 1A and 2A); this effect was completely erased by the concomitant use of humic acids (Tables 1B and 2B).

\subsubsection{Comet assay}

The data obtained with the Comet assay in erythrocytes of $C$. carpio exposed in situ to different concentrations of $\mathrm{NaClO}, \mathrm{ClO}_{2}$ and PAA with or without $\mathrm{HA}$ are reported as median TM values in Table 1. The data concerning the percentage of ghost cells detected, which was never $>10 \%$ and did not show a clear dose-response relationship, are not reported.

The comparison of the DNA migration detected in the fish population at the beginning $(t=0)$ of exposure and that in the two control populations $(0 \mathrm{ppm})$ at the end of the exposure time ( $t=3$ days) in well-water without (Table 1A) or with (Table 1B) humic acids did not show any significant differences.

After 3 days of exposure ( $t=3$ days), an overall reduction in migration compared with the control population $(0 \mathrm{ppm})$ was found with the two pure chlorine-containing disinfectants without humic acids (Table 1A). The effects were significant $(P<0.01)$ for $0.1 \mathrm{ppm} \mathrm{NaClO}$. Significant variations in DNA migration were not observed in the presence of humic acids (Table 1B) at this time point.

\subsubsection{Micronucleus test}

The observed frequencies from MN analysis are presented in Table 2. Micronucleus frequencies of all fish populations sampled at the start $(t=0)$ were very similar, indicating a good homogeneity in the starting conditions.

No significant increase in MN frequency was found in blood samples taken at $t=15$ and 30 days compared with samples taken at $t=0$, for fish populations exposed to disinfectants alone. Significant dose-dependent increases in $\mathrm{MN}$ frequency (linear regression analysis) were found for some experimental points only (Table 3 ).

On the other hand, significant increases in MN frequency were found for blood samples taken at successive time points compared with samples taken at $t=0$, in fish populations exposed to $\mathrm{NaClO}+\mathrm{HA}$, at

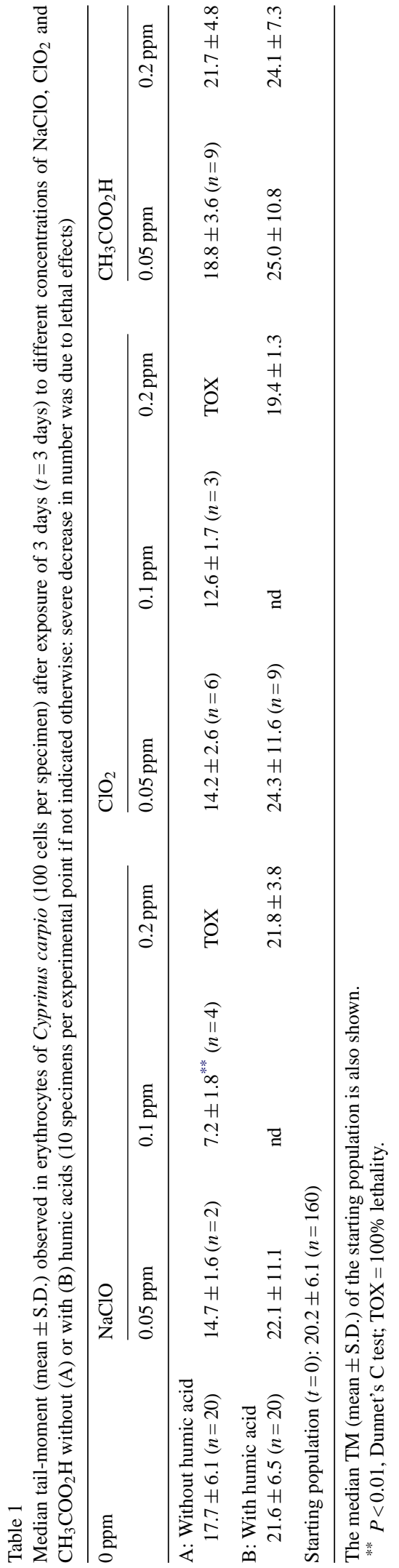


Table 2

Mean frequency values ( \pm S.E.) of micronuclei (MN/20,000 cells) observed in erythrocytes of Cyprinus carpio (20,000 cells per specimen) after $72 \mathrm{~h}$ exposure to different concentrations (0.05-0.2 ppm) of $\mathrm{NaClO}, \mathrm{ClO}_{2}$ and $\mathrm{CH}_{3} \mathrm{COO}_{2} \mathrm{H}$ without (A) or with (B) humic acids (0.1 ppm TOC)

\begin{tabular}{|c|c|c|c|c|c|c|c|c|}
\hline \multirow[t]{2}{*}{ Control } & \multicolumn{3}{|l|}{$\mathrm{NaClO}$} & \multicolumn{3}{|l|}{$\mathrm{ClO}_{2}$} & \multicolumn{2}{|l|}{$\mathrm{CH}_{3} \mathrm{COO}_{2} \mathrm{H}$} \\
\hline & $0.05 \mathrm{ppm}$ & $0.1 \mathrm{ppm}$ & $0.2 \mathrm{ppm}$ & $0.05 \mathrm{ppm}$ & $0.1 \mathrm{ppm}$ & $0.2 \mathrm{ppm}$ & $0.05 \mathrm{ppm}$ & $0.2 \mathrm{ppm}$ \\
\hline \multicolumn{9}{|l|}{$\begin{array}{l}\text { A: Without humic acid } \\
\qquad t=0\end{array}$} \\
\hline $0.30 \pm 0.13(n=20)$ & $0.20 \pm 0.13$ & $0.40 \pm 0.22$ & nd & $0.50 \pm 0.22$ & $0.40 \pm 0.16$ & nd & $0.30 \pm 0.21$ & $0.0 \pm 0.15$ \\
\hline $\begin{array}{l}t=15 \text { days } \\
\quad 0.35 \pm 0.13(n=20)\end{array}$ & $1.00 \pm 0.00(n=2)$ & $0.75 \pm 0.48(n=4)$ & TOX & $0.50 \pm 0.34(n=6)$ & $1.67 \pm 0.33(n=3)$ & TOX & $0.33 \pm 0.16(n=9)$ & $0.80 \pm 0.25$ \\
\hline $\begin{array}{l}t=30 \text { days } \\
\quad 0.35 \pm 0.13(n=20)\end{array}$ & $1.50 \pm 0.50(n=2)$ & $1.25 \pm 0.25(n=4)$ & TOX & $1.00 \pm 0.36(n=6)$ & $1.00 \pm 0.58(n=3)$ & TOX & $0.44 \pm 0.17(n=9)$ & $1.20 \pm 0.33$ \\
\hline \multicolumn{9}{|l|}{$\begin{array}{l}\text { B: With humic acid } \\
\qquad t=0\end{array}$} \\
\hline $0.40 \pm 0.13(n=20)$ & $0.30 \pm 0.15$ & nd & $0.50 \pm 0.22$ & $0.33 \pm 0.24(n=9)$ & nd & $0.20 \pm 0.13$ & $0.40 \pm 0.16$ & $0.40 \pm 0.22$ \\
\hline $\begin{array}{l}t=15 \text { days } \\
\quad 0.40 \pm 0.13(n=20)\end{array}$ & $1.00 \pm 0.26$ & nd & $2.20 \pm 0.29^{* *}$ & $0.70 \pm 0.26$ & nd & $1.40 \pm 0.42^{*}$ & $0.50 \pm 0.22$ & $1.10 \pm 0.23$ \\
\hline $\begin{array}{l}t=30 \text { days } \\
\quad 0.60 \pm 0.15(n=20)\end{array}$ & $1.30 \pm 0.30^{*}$ & nd & $2.90 \pm 0.53^{* * *}$ & $0.90 \pm 0.23$ & nd & $1.70 \pm 0.39^{* *}$ & $0.70 \pm 0.30$ & $1.10 \pm 0.31$ \\
\hline $\begin{array}{l}\text { Statistical comparisons we } \\
\text { and } 15 \text { or } 30 \text { days }\left(t_{1}=15\right. \\
\text { numbers were due to letha } \\
{ }^{*} P<0.05 \text { (Mann-Whitn } \\
{ }^{* *} \quad P<0.01 \text { (Mann-Whitn } \\
{ }^{* * *} P<0.001 \text { (Mann-Whit }\end{array}$ & $\begin{array}{l}\text { nade for each treate } \\
\text { s, } t_{2}=30 \text { days) afte } \\
\text { fects). } \\
\text { test). } \\
\text { test). } \\
\text { test). }\end{array}$ & $\begin{array}{l}\text { oup between blood } \\
\text { start of exposure. }\end{array}$ & $\begin{array}{l}\text { ples at } t=0 \text { and } \\
\text { specimens per }\end{array}$ & $\begin{array}{l}t=15 \text { or } 30 \text {. Three } \\
\text { erimental point }(2\end{array}$ & $\begin{array}{l}\text { ling times are stud } \\
\text { controls) were an }\end{array}$ & $\begin{array}{l}\text { mmediately b } \\
d \text {, when not ir }\end{array}$ & $\begin{array}{l}\text { e the beginning of } \\
\text { ated otherwise (sev }\end{array}$ & $\begin{array}{l}\text { osure }\left(t_{0}=0\right) \\
\text { decreases in }\end{array}$ \\
\hline
\end{tabular}

**** $P<0.001$ (Mann-Whitney test) 
Table 3

Results of linear regression analysis on micronucleus (MN) frequencies in fish erythrocytes (see Table 2), obtained from a 72-h exposure to different concentrations (range: $0.05-0.2 \mathrm{ppm}$ ) of $\mathrm{NaClO}, \mathrm{ClO}_{2}$ and $\mathrm{CH}_{3} \mathrm{COO}_{2} \mathrm{H}$ with (+) or without (-) humic acids (HA: $0.1 \mathrm{ppm}$ TOC): two sampling times (15 and 30 days) were examined after the treatment

\begin{tabular}{|c|c|c|c|}
\hline Disinfectant & $\begin{array}{l}\text { Humic } \\
\text { acids }\end{array}$ & Slope & $\begin{array}{l}\text { Correlation } \\
\text { coefficient }(r)\end{array}$ \\
\hline $\mathrm{NaClO}$ (15 days) & - & 0.0213 & 0.240 \\
\hline $\mathrm{NaClO}$ (30 days) & - & $0.0471^{*}$ & 0.491 \\
\hline $\mathrm{ClO}_{2}$ (15 days) & - & $0.0639^{* *}$ & 0.536 \\
\hline $\mathrm{ClO}_{2}$ (30 days) & - & 0.0377 & 0.316 \\
\hline $\mathrm{CH}_{3} \mathrm{COO}_{2} \mathrm{H}$ (15 days) & - & 0.0230 & 0.302 \\
\hline $\mathrm{CH}_{3} \mathrm{COO}_{2} \mathrm{H}$ (30 days) & - & $0.0430^{* *}$ & 0.460 \\
\hline $\mathrm{NaClO}$ (15 days) & + & $0.0893^{* * *}$ & 0.714 \\
\hline $\mathrm{NaClO}$ (30 days) & + & $0.1144^{* * *}$ & 0.675 \\
\hline $\mathrm{ClO}_{2}$ (15 days) & + & $0.0498^{* *}$ & 0.430 \\
\hline $\mathrm{ClO}_{2}$ (30 days) & + & $0.0550^{* *}$ & 0.475 \\
\hline $\mathrm{CH}_{3} \mathrm{COO}_{2} \mathrm{H}$ (15 days) & + & $0.0363^{* *}$ & 0.444 \\
\hline $\mathrm{CH}_{3} \mathrm{COO}_{2} \mathrm{H}$ (30 days) & + & 0.0251 & 0.248 \\
\hline
\end{tabular}

\footnotetext{
* $P<0.05$ : referred to the slope value (significantly different from $0)$.

** $P<0.01$ : referred to the slope value (significantly different from $0)$.

${ }^{* * *} P<0.001$ : referred to the slope value (significantly different from $0)$.
}

both $0.2 \mathrm{ppm}(t=15$ and 30 days $)$ and $0.05 \mathrm{ppm}(t=30$ days), as well as $\mathrm{ClO}_{2}+\mathrm{HA}$ at $0.2 \mathrm{ppm}(t=15$ and 30 days). A significant dose-dependent increase in $\mathrm{MN}$ frequency (linear regression analyses) was shown for the chlorinated disinfectants with $\mathrm{HA}$ at both sampling times, and for PAA at $t=15$ days. The slopes, correlation coefficient $(r)$ and $P$-values are shown in Table 3.

A clear clastogenic and/or aneugenic effect is induced by chlorinated disinfectants, mainly $\mathrm{NaClO}$, only in the presence of HA, as shown by the MN test.

\section{Discussion}

The ubiquitous occurrence of trihalomethanes in chlorinated drinking-water and their potential carcinogenic impact has attracted considerable attention. Furthermore, a variety of both chlorinated and nonchlorinated organic products has been shown to be formed as a result of disinfection of water that contains humic material $[1-3,62]$.

In this context, the present study was focused on the assessment of in vivo genotoxic effects on $C$. carpio exposed to different disinfectants in the presence or absence of standard HA. The exposure of fish populations shows evidence for lethal effects induced by the pure disinfectants $\mathrm{NaClO}$ and $\mathrm{ClO}_{2}$, dissolved in the well-water, i.e. in the absence of HA. In particular, the 0.2 -ppm concentration of the two chlorinated disinfectants $\left(\mathrm{NaClO}\right.$ and $\left.\mathrm{ClO}_{2}\right)$ appears to be highly toxic, so as to induce $100 \%$ lethality within the first $24 \mathrm{~h}$ of exposure. High toxicity is still evident even at diminishing disinfectant concentrations. A 'protective effect' of HA against these toxic effects could be suggested by the lack of mortality in fishes exposed to HA-pretreated disinfectant solutions. These findings are in agreement with our previous studies [18] where no lethal effects were detected in C. carpio exposed to lake waters with high HA content that were disinfected with comparable chlorine concentrations. Aquatic humic acids have also been found to decrease acute toxicity of a pyrethroid pesticide in grass carp [63].

In general, pure chlorinated disinfectants induced a slight - although not significant - increase in MN frequency with time (up to 30 days) in exposed fish. Beside high toxicity, a weak genotoxic effect was detected by the Comet assay, where a significant reduction of DNA migration was found in surviving specimens after exposure to $0.1 \mathrm{ppm} \mathrm{NaClO}$ and, in a non-significant way, $\mathrm{ClO}_{2}$. In the Comet assay, a reduction of DNA migration can be related to intrastrand and interstrand DNA crosslinks $[64,65]$. A reduction in DNA migration, explained as DNA cross-linking, was reported in mice exposed in vivo to dichloroacetic acid, a major disinfection byproduct of water chlorination [66]. Pommery et al. [53] proposed that cross-linking by-products could be derived from interactions of chlorine disinfectants with organic molecules present at very low concentrations (high $\mathrm{Cl}: \mathrm{C}$ ratio) in well-water.

Pre-incubation of chlorinated disinfectants with HA induces clastogenic and/or aneugenic effects, as is shown by the MN test, in which a trend of increasing $\mathrm{MN}$ frequency with time (up to 30 days) was detected. This is in agreement with other results previously obtained on carp erythrocytes $[33,36,41,18]$ and explained by the slow release of $\mathrm{MN}$-containing erythrocytes from their stem tissue, the cephalic kidney. These results are confirmed by the dose-dependent increase in $\mathrm{MN}$ frequency, suggesting that genotoxic by-products are generated by the interaction of these chlorinated disinfectants with $\mathrm{HA}$. The observed genotoxic effects of $\mathrm{NaClO}+\mathrm{HA}$ and of $\mathrm{ClO}_{2}+\mathrm{HA}$ are in accordance with results obtained from previous studies [18] on MN-carp erythrocytes after in situ exposures to similar concentrations of the disinfectants. The present results are also in agreement with those obtained from in situ plant genotoxicity tests, where clear clastogenic/aneugenic effects of $\mathrm{NaClO}$ - and $\mathrm{ClO}_{2}$-disinfected surface waters were reported in different monitoring seasons [22]. Mutagenic activity induced 
by chlorinated humic acid compounds was also shown in bacteria $[52,1,2]$. On the other hand, the Comet assay did not detect any significant increase or decrease in DNA migration.

The absence of direct, Comet-detectable primary DNA damage could be related to the $\mathrm{Cl}: \mathrm{C}$ ratios used in our experiments (1:0.32 or 1:0.08), which are lower than those detected from in situ exposures $[21,18]$. Furthermore, the data on erythrocytes sampled after 3 days of exposure could be the result of a balance among DNA damage induction, DNA repair processes, and apoptotic events with elimination of damaged cells. The negative results obtained by the Comet assay on the 3rd day from the beginning of a continuous exposure, compared with the positive outcome obtained at an earlier sampling time $(3 \mathrm{~h})$ in our previous study [18], seem to suggest that 3 days may be a sampling time that is too long, presumably inadequate for the test in this cell system. Unlike stem cells that undergo cell-cycle progression and full DNA metabolism, circulating erythrocytes might differ, e.g. in terms of repair-system efficacy, and heavily damaged cells may undergo elimination from the erythrocyte cell population within a short lapse of time. Conversely, the occurrence of repair mechanisms, together with an adaptive response to genotoxic exposure, might explain the absence of damaged cells.

Positive results from the MN test - without concomitant DNA damage detectable by the Comet assay - induced by $\mathrm{NaClO}$ and $\mathrm{ClO}_{2}$ with $\mathrm{HA}$ treatments could be due to a specific response of circulating erythrocytes towards stress, such as detoxication of by-products $[67,68]$; on the other hand, in stem cells of the cephalic kidney the primary damage may undergo DNA repair, eventually leading to chromosome breakage, detectable as micronuclei in circulating erythrocytes, several days later. Another possible explanation is that the MN test can detect aneugenic effects also.

Chlorination of HA involves a highly complex sequence of reactions. It is essentially an oxidative, halogenating, degradation process with simultaneous substitution, addition, elimination, rearrangement and hydrolytic reactions taking place, resulting in a large variety of end products, not all fully characterized [5,62]. This chain of reactions is highly dependent upon the level of chlorination, total organic carbon, and other physico-chemical parameters [5,53]. Many of the halogenated compounds are direct-acting mono- or bifunctional alkylating agents and possibly responsible for a significant part of the mutagenic activity of the chlorinated humic acids detected in the Salmonella microsome assay [5]. Pommery et al. [53] showed that a low con- centration of chlorine together with HA was unable to produce by-products with significant genotoxic activity. Hutchinson et al. [19] did not find any significant genetic damage in embryo-larval polychaetes exposed to $\mathrm{NaClO}$-disinfected sewage, i.e. in the presence of high concentrations of organics. Pommery et al. [53] suggested that, at low concentration, chlorine may damage humic materials without complete degradation, whereas at high concentrations it can also react with first-formed reaction intermediates, thereby producing genotoxic byproducts.

The dose-dependent increase in MN frequency found for PAA, both in combination with HA and alone, suggests that its genotoxic intermediate(s) can be produced independently of the organic carbon content of treated waters. Its effect was not detectable by the Comet assay. Negative results on genotoxic effects of PAA have also been reported [18] with $C$. carpio erythrocytes. The Comet assay was able to detect the genotoxic activity of pure PAA with an increase in DNA migration, measured $1 \mathrm{~h}$ after the beginning of exposure, in human lymphocytes [69]. Positive results have also been reported [22] in plant genotoxicity assays after in situ exposure to surface waters disinfected with $\mathrm{NaClO}, \mathrm{ClO}_{2}$ and PAA. The genotoxicity of PAA was found to be lower than that induced by the two other chlorinated disinfectants.

Pure chlorinated disinfectants appeared to be highly toxic and their genotoxic potential could not be pointed out within the present experimental schedule. On the other hand, two main effects of humic acids could be observed: (i) a genotoxic effect after their reaction with chlorinated compounds and (ii) a protective effect against the toxicity of the chlorinated compounds, the reduction of which rendered the clastogenic effects detectable.

The use of the in vivo Comet assay and MN test, together with evaluation of survival, has enabled us to point out the complexity of the reaction pathways of the different disinfectants, especially chlorine biocides and/or their by-products with organic compounds present in the water.

\section{Acknowledgements}

The study was supported by the Italian Ministry of Education, University and Scientific Research (MIUR, 2001: 'Studies on mutagenic effects of drinking-water sampled in different sites of the pipeline systems and of disinfectants for potabilization with/without humic acids, using the MN test in plants and fish'). 


\section{References}

[1] J.R. Meier, R.D. Lingg, R.J. Bull, Formation of mutagens following chlorination of humic acid: a model for mutagen formation during drinking water treatment, Mutat. Res. 118 (1983) 2541.

[2] J.R. Meier, H.P. Ringhand, W.E. Coleman, J.W. Munch, R.P. Streicher, W.H. Kaylor, K.M. Schenck, Identification of mutagenic compounds formed during chlorination of humic acid, Mutat. Res. 151 (1985) 111-112.

[3] World Health Organization, Revision of the WHO Guidelines for Drinking Water Quality, World Health Organization, Geneva, Switzerland, 1996.

[4] J.R. Meier, H.P. Ringhand, W.E. Coleman, K.M. Schenck, J.W. Munch, R.P. Streicher, W.H. Kaylor, F.C. Kopfler, Mutagenic by-products from chlorination of humic acid, Environ. Health Perspect. 69 (1986) 101-107.

[5] S.C. Agarwal, J. Neton, Mutagenicity and alkylating activity of the aqueous chlorination products of humic acid and their molecular weight fractions, Sci. Total Environ. 79 (1989) $69-83$.

[6] International Agency for Research on Cancer (IARC), IARC Monograph on the Evaluation of Carcinogenic Risk to Humans, Chlorinated Drinking-Water; Chlorination By-Products; Some Other Halogenated Compounds; Cobalt and Cobalt Compound, vol. 52, 1991.

[7] International Agency for Research on Cancer (IARC), IARC Monograph on the Evaluation of Carcinogenic Risk to Humans, Some Drinking-Water Disinfectants and Contaminants, Including Arsenic, vol. 84, 2002.

[8] N.H. Woodruff, J.L. Durant, L.L. Donhoffner, B.W. Penman, C.L. Crespi, Human cell mutagenicity of chlorinated and unchlorinated water and the disinfection byproduct, Mutat. Res. 495 (2001) $157-168$.

[9] K.T. Cantor, Drinking water and cancer, Cancer Causes Control. 8 (1997) 292-308.

[10] T.J. Doyle, W. Zheng, J.R. Cerhan, C.P. Hong, T.A. Sellers, L.H. Kushi, A.R. Folsom, The association of drinking water source and chlorination by-products with cancer incidence among postmenopausal women in Iowa: a prospective cohort study, Am. J. Public Health 87 (1997) 1168-1176.

[11] M. Koivusalo, E. Pukkala, T. Vartiainen, Drinking water chlorination and cancer-a historical cohort study in Finland, Cancer Causes Control. 8 (1997) 192-200.

[12] X. Tao, H. Zhu, G.M. Matanoski, Mutagenic drinking water and risk of male esophageal cancer: a population-based case-control study, Am. J. Epidemiol. 150 (1999) 443-451.

[13] M. Soffritti, F. Belpoggi, A. Lenzi, C. Maltoni, Results of longterm carcinogenicity studies of chlorine in rats, Ann. N. Y. Acad. Sci. 26 (1997) 189-208.

[14] A. Jaylet, P. Deparis, V. Ferrier, S. Grinfeld, R. Siboulet, A new micronucleus test using peripheral blood erythrocytes of the newt Pleurodeles waltl to detect mutagens in fresh-water pollution, Mutat. Res. 164 (1986) 245-257.

[15] A. Jaylet, L. Gauthier, M. Fernandez, Detection of mutagenicity in drinking water using a micronucleus test in newt larvae (Pleurodeles Waltl), Mutagenesis 2 (1987) 211-214.

[16] M. Fernandez, L. Gauthier, A. Jaylet, Use of newt larvae for in vivo genotoxicity testing of water: results on 19 compounds evaluated by the micronucleus test, Mutagenesis 4 (1989) 17-26.

[17] F. Le Curieux, S. Giller, L. Gauthier, F. Erb, D. Marzin, Study of the genotoxic activity of six alogenated acetonitriles, using the
SOS chromotest, the Ames-fluctuation test and the newt micronucleus test, Mutat. Res. 341 (1995) 289-302.

[18] A. Buschini, A. Martino, B. Gustavino, M. Monfrinotti, P. Poli, C. Rossi, M. Santoro, A.J.M. Doerr, M. Rizzoni, Comet assay and micronucleus test in circulating erythrocytes of Ciprinus carpio specimens exposed to lake waters treated with disinfectants for potabilization, Mutat. Res. 557 (2004) 119129.

[19] T.H. Hutchinson, A.N. Jha, J.M. Mackay, B.M. Elliot, D.R. Dixon, Assessment of developmental effects, cytotoxicity and genotoxicity in the marine polychaete (Platinereis dumerilii) exposed to disinfected municipal seawage effluents, Mutat. Res. 399 (1998) 97-108.

[20] C. Bolognesi, A. Buschini, E. Branchi, P. Carboni, M. Furlini, A. Martino, M. Monteverde, P. Poli, C. Rossi, Comet and micronucleus assays in zebra mussel cells for genotoxicity assessment of surface drinking water treated with three different disinfectants, Sci. Total Environ. 333 (2004) 127-136.

[21] T.H. Ma, V.A. Anderson, M.M. Harris, R.E. Neas, T.S. Lee, Mutagenicity of drinking water detected by the Tradescantia micronucleus test, Can. J. Genet. Cytol. 27 (1985) 143-150.

[22] S. Monarca, M. Rizzoni, B. Gustavino, C. Zani, A. Alberti, D. Ferretti, I. Zerbini, Genotoxicity of surface water treated with different disinfectants using in situ plant test, Environ. Mol. Mutagen. 41 (2003) 353-359.

[23] M.G.C. Baldry, M.S. French, D. Slater, The activity of peracetic acid on sewage indicator bacteria and viruses, Water Sci. Technol. 24 (2) (1991) 353-357.

[24] M.G.C. Baldry, A. Cavadore, M.S. French, G. Massa, L.M. Rodrigues, P.F.T. Schirch, T.L. Threadgold, Effluent disinfection in warm climates with peracetic acid, Water Sci. Technol. 31 (56) (1995) 161-164.

[25] F. Lefevre, J.M. Audic, F. Ferrand, Peracetic acid disinfection of secondary effluents discharged off coastal seawater, Water Sci. Technol. 25 (1992) 155-164.

[26] S. Monarca, S.D. Richardson, D. Feretti, M. Grottolo, A.D. Thruston, C. Zani, G. Navazio, P. Ragazzo, I. Zerbini, A. Alberti, Mutagenicity and disinfection by-products in surface drinking water disinfected with peracetic acid, Environ. Toxicol. Chem. 21 (2002) 309-318.

[27] M.L. Landolt, R.M. Kocan, Fish cell cytogenetics: a measure of genotoxic effects of environmental pollutants, in: J.O. Nriagu (Ed.), Aquatic Toxicology, J. Wiley and Sons Inc., NY, 1983, pp. 335-352.

[28] K. Al Sabti, C.D. Metcalfe, Fish micronuclei for assessing genotoxicity in water, Mutat. Res. 343 (1995) 121-135.

[29] J.E. Hose, J.N. Cross, S.G. Smith, D. Diehl, Elevated circulating erythrocyte micronuclei in fishes from contaminated sites of Southern California, Mar. Environ. Res. 22 (1987) 167-176.

[30] W.D. Gronlund, S.L. Chan, B.B. McCain, R.C. Clark, M.S. Meyers, J.E. Stein, D.W. Brown, J.T. Landahl, M.M. Krahn, U. Varnasi, Multidisciplinary assessment of pollution at three sites in long Island Sound, Estuaries 14 (1991) 299-305.

[31] J.B. Hughes, A.T. Herbert, Erythrocyte micronuclei in Winter Flounder (Pseudopleuronectes americanus): result of field surveys during 1980-1988 from Virginia to Nova Scotia and in Long Island Sound, Arch. Environ. Contam. Toxicol. 20 (1991) 474-479.

[32] S. De Flora, L. Viganò, F. D’Agostini, A. Camoirano, M. Bagnasco, C. Bennicelli, F. Melodia, A. Arrillo, Multiple genotoxicity biomarkers in fish exposed in situ to polluted river water, Mutat. Res. 319 (1993) 167-177. 
[33] S. Minissi, E. Ciccotti, M. Rizzoni, Micronucleus test in erythrocytes of Barbus plebejus (Teleostei, Pisces) from two natural environments: a bioassay for the in situ detection of mutagens in freshwater, Mutat. Res. 367 (1996) 245-251.

[34] R.N. Hooftman, W.K. de Raat, Induction of nuclear anomalies (micronuclei) in the peripheral blood erythrocytes of the eastern mudminnow Umbra pygmaea by ethyl methansulphonate, Mutat. Res. 104 (1982) 147-152.

[35] R.K. Das, N.K. Nanda, Induction of micronuclei in peripheral erythrocytes of fish Heteropneustes fossilis by mitomycin $\mathrm{C}$ and paper mill effluents, Mutat. Res. 175 (1986) 67-71.

[36] N. Schultz, L. Norrgren, J. Gawe, A. Johannisson, O. Medhage, Micronucleus frequency in circulating erythrocytes from rainbow trout (Oncorhynchus mykiss) subject to radiation, an image analysis and flow cytometric study, Comp. Biochem. Physiol. 105C (1993) 207-211.

[37] I.B. Bahari, F.M. Noor, N.M. Daud, Micronucleated erythrocytes as an assay to assess actions by physical and chemical genotoxic agents in Clarias gariepinus, Mutat. Res. 313 (1994) 1-5.

[38] F. Ayllon, E. Garcia-Vasquez, Induction of micronuclei and other nuclear abnormalities in European minnow Phoxinus phoxinus and mollie Poecilia latipinna: an assessment of the fish micronucleus test, Mutat. Res. 467 (2000) 177-186.

[39] K. Al Sabti, Clastogenic effect of five carcinogenic-mutagenic chemicals on the cells of the common carp Cyprinus carpio L, Comp. Biochem. Physiol. 85 (1986) 5-9.

[40] J.C. Nepomuceno, I. Ferrari, M.A. Spanò, A.J. Centeno, Detection of micronuclei in peripheral erythrocytes of Cyprinus carpio exposed to metallic mercury, Environ. Mol. Mutagen. 30 (1997) 293-297.

[41] B. Gustavino, K.A. Scornajenghi, S. Minissi, E. Ciccotti, Micronuclei induced in erythrocytes of Cyprinus carpio (Teleostei, Pisces) by X-rays and colchicine, Mutat. Res. 494 (2001) 151-159.

[42] A.J. Davidson, L.I. Zon, The definitive (and primitive) guide to zebrafish hematopoiesis, Oncogene 23 (2004) 7233-7246.

[43] WT. Catton, Blood cell formation in certain teleost fishes, Blood 6 (January) (1951) 39-60.

[44] G.M. Alink, E.M.H. Frederix-Wolters, M.A. van der Gaag, J.F.J. van der Kerkhoff, C.L.M. Poels, Induction of sister chromatid exchanges in fish exposed to Rhine water, Mutat. Res. 78 (1980) 369-374.

[45] J. Bejar, J.J. Borrego, M.C. Alvarez, A continuous cell line from the cultured marine fish gilt-head seabream (Sparus aurata L), Aquaculture 150 (1997) 143-153.

[46] A.R. Pombinho, V. Laizé, D.M. Molha, S.M.P. Marques, M.L. Cancela, Development of two bone-derived cell lines from the marine teleost Sparus aurata; evidence for extracellular matrix mineralization and cell-type-specific expression of matrix Gla protein and osteocalcin, Cell Tissue Res. 315 (2004) 393-406.

[47] M. Nikinmaa, How does environmental pollution affect red cell function in fish? Aquat. Toxicol. 22 (1992) 227-238.

[48] C.L. Mitchelmore, J.K. Chipman, Detection of DNA strand breaks in brown trout (Salmo trutta) hepatocytes and blood cells using the single cell gel electrophoresis (comet) assay, Aquat. Toxicol. 41 (1998) 161-182.

[49] R. Pandragi, M. Petras, S. Ralph, M. Vrzoc, Alkaline single cell gel (Comet) assay and genotoxicity monitoring using bullheads and carp, Environ. Mol. Mutagen. 26 (1995) 345-356.

[50] D.R. Dixon, A.M. Pruski, L.R.J. Dixon, A.N. Jha, Marine invertebrates eco-toxicology: a methodological overview, Mutagenesis 17 (2002) 495-507.
[51] G. Reiffersheid, T. Grummt, Genotoxicity in German surface waters-results of a collaborative study, Water Air Soil Pollut. 123 (2000) 67-79.

[52] B.L. Van Duuren, S. Melchionne, I. Seidman, M.A. Pereira, Chronic bioassays of chlorinated humic acids in B6C3F1 mice, Environ. Health Perspect. 69 (1986) 109-117.

[53] J. Pommery, M. Imbenotte, A.F. Urien, D. Marzin, F. Erb, SOS Chromotest study concerning some appreciation criteria of humic substances' genotoxic potency, Mutat. Res. 223 (1989) 183189.

[54] APHA, Standard Methods for the Examinations of Waters and Wastewaters, 17th ed., American Public Health Association, Washington, DC, 1989.

[55] APHA, Standard Methods for the Examinations of Waters and Wastewaters, 20th ed., American Public Health Association, Washington, DC, 1998.

[56] M. Sumathi, K. Kalaiselvi, M. Palanivel, P. Rajaguru, Genotoxicity of textile dye effluent on fish (Cyprinus carpio) measured using the comet assay, Bull. Environ. Contam. Toxicol. 66 (2001) 407-414.

[57] P. Rajaguru, S. Suba, M. Palanivel, K. Kalaiselvi, Genotoxicity of a polluted river system measured using the alkaline comet assay on fish and earthworm tissues, Environ. Mol. Mutagen. 41 (2003) $85-91$

[58] N.P. Singh, M.T. Mc Coy, R.R. Tice, E.L. Schneider, A simple technique for quantitation of low levels of DNA damage in indivindual cells, Exp. Cell Res. 175 (1998) 184-191.

[59] S. Meintières, F. Nesslany, M. Pallardy, D. Marzin, Detection of ghost cells in the standard alkaline Comet assay is not a good measure of apoptosis, Environ. Mol. Mutagen. 41 (2003) 260269.

[60] K. Belpaeme, K. Delbeke, L. Zhu, M. Kirsh-Volders, Cytogenetic studies of PCB77 on brown trout (Salmo trutta fario) using the micronucleus test and the alkaline comet assay, Mutagenesis 11 (1996) 485-492.

[61] G.A. Wedmeyer, Effects of rearing condition on the health and physiologic quality of fish in intensive culture, in: G.K. Iwama, A.D. Pickering, J.P. Sumpter, C.B. Schreck (Eds.), Fish Stress and Health in Aquaculture, Soc. Exp. Biol. Seminar Series, vol. 62, Cambridge University Press, 1997, pp. 35-71.

[62] T. Nobukawa, S. Sanukida, Effect of bromide ions on genotoxicity of halogenated by-products from chlorination of humic acid in water, Water Res. 35 (2001) 4293-4298.

[63] W.Z. Wu, Y. Xu, K. Schramm, A. Kettrup, Effect of natural dissolved humic material on bioavailability and acute toxicity of fenpropathrin to the grass carp, Ctenopharyngodon idellus, Ecotoxicol. Environ. Saf. 42 (1999) 203-206.

[64] O. Merk, G. Speit, Detection of crosslinks with the comet assay in relationship to genotoxicity and cytotoxicity, Environ. Mol. Mutagen. 33 (1999) 167-172.

[65] R.R. Tice, E. Agurell, D. Anderson, B. Burlinson, A. Hartmann, H. Kobayashi, Y. Miyamae, E. Rojas, J.-C. Ryu, Y.F. Sasaki, Single cell gel/Comet assay: guideline for in vitro and in vivo genetic toxicology testing, Environ. Mol. Mutagen. 35 (2000) 206-221.

[66] J.C. Fuscoe, A.J. Afshari, M.H. George, A.B. DeAngelo, R.R. Tice, T. Salman, J.W. Allen, in vivo genotoxicity of dichloroacetic acid: evaluation with the mouse peripheral micronucleus assay and the single cell gel assay, Environ. Mol. Mutagen. 27 (1996) $1-9$.

[67] J.R. Meier, A.B. DeAngelo, F.B. Daniel, K.M. Schenck, J.W. Doerger, L.W. Chang, F.C. Kopler, M. Robinson, H.P. Ringhand, Genotoxic and carcinogenic properties of chlorinated fura- 
nones, important by-products of water chlorination, in: M.D. Waters, F.B. Daniel, J. Lewtas, M.M. Moore, S. Nesnow (Eds.), Genetic Toxicology of Complex Mixtures, Plenum, New York, 1990.

[68] G. Ubom, J.K. Chipman, Absence of unscheduled DNA synthesis in rat hepatocytes treated with mutagenic and cytotoxic chlorinated humic substances, Mutat. Res. 321 (1994) 5763.

[69] A. Buschini, P. Carboni, M. Furlini, P. Poli, C. Rossi, Sodium hypochlorite-, chlorine dioxide-, and peracetic acid-induced genotoxicity detected by the Comet assay and Saccharomyces cerevisiae D7 tests, Mutagenesis 19 (2004) 157-162. 